\title{
The Bacillus subtilis clpC operon encodes DNA repair and competence proteins
}

\author{
Elke Krüger, ${ }^{1}$ Tarek Msadek, ${ }^{2}$ Steffen OhImeier ${ }^{1}$ and Michael Hecker ${ }^{1}$
}

1 Institut für Mikrobiologie und Molekularbiologie, Ernst-Moritz-ArndtUniversität, D-17487 Greifswald, Germany

2 Unité de Biochimie Microbienne, Unité de Recherche Associee 1300 du Centre National de la Recherche Scientifique, Institut Pasteur, 25 Rue du Dr Roux, 75724 Paris Cedex 15, France

\author{
Author for correspondence: Michael Hecker. Tel: +49 3834 864200. Fax : 3834864202. \\ e-mail: hecker@microbio7.biologie.uni-greifswald.de
}

\begin{abstract}
ClpC of Bacillus subtilis, controlling competence gene expression and survival under stress conditions, is encoded by the fourth gene of a six-gene operon. The product of orf1 contains a potential helix-turn-helix motif, but shows no significant similarities with known protein sequences. The second and third genes encode proteins with similarities to zinc-finger proteins (orf2) and arginine kinases (orf3), respectively. The product of orf5 contains a zinc-finger motif and an ATP-binding domain, and is highly similar to the product of the Escherichia coli sms gene. A strain bearing a disruption of orf5 showed increased sensitivity to the alkylating agent methyl methanesulfonate. Furthermore, this mutant strain displayed decreased capacity for genetic recombination as measured by transformation experiments. The last open reading frame, orf6, encodes a protein with limited similarity in its C-terminal part to the $B$. subtilis comEA gene product and to the UvrC DNA repair excinuclease. Inactivation of orf5 resulted in strongly diminished transformation with all types of DNA. Mutations affecting either orf5 or orf6 resulted in strains with decreased resistance to UV-irradiation in the stationary phase, indicating that these proteins play a role in the development of a nonspecific stationary-phase resistance to UV-irradiation. Moreover, these results suggest an involvement of both proteins in transformation and presumably in DNA repair.
\end{abstract}

Keywords: stress proteins, Bacillus subtilis, ClpC, DNA repair, competence

\section{INTRODUCTION}

For soil bacteria such as Bacillus subtilis the ability to survive unfavourable environmental conditions is crucial. In order to respond to stressful situations or starvation, the cell has developed an adaptive network including stress responses and post-exponential-phase phenomena such as the development of genetic competence, motility, synthesis of degradative enzymes and finally sporulation. These processes are controlled by a complex and incompletely understood regulatory network accompanied by interactions and overlaps between the components (Msadek et al., 1995).

Genetic competence of B. subtilis, the ability to take up exogenous DNA molecules, is controlled by many regulatory genes, such as $s p o 0 A, \operatorname{comP}, \operatorname{com} A$, $\operatorname{deg} U$, coms, mecA, clpC/mecB and comK. These genes are required for appropriate expression of the late com-

Abbreviation: MMS, methyl methanesulfonate. petence genes, encoding DNA-binding and -uptake enzymes (Dubnau et al., 1994). Moreover, the SOS system is also part of the competence response, and is subject to a dual regulation: a damage-inducible pathway and a competence-dependent induction (Dubnau, 1991; Cheo et al., 1993).

Synthesis of bacterial stress proteins is induced by a wide variety of factors including heat shock, ethanol stress, $\mathrm{pH}$ and osmolarity changes, UV-irradiation, hydrogen peroxide, DNA-damaging agents and starvation (Bukau, 1993; Hecker et al., 1996). ClpC, a member of the stress-response-related Clp-ATPase family, is a pleiotropic regulator involved in stress tolerance and cell division (Krüger et al., 1994). The ClpC protein was also identified as $\mathrm{MecB}$, controlling competence and synthesis of degradative enzymes (Msadek et al., 1994). Therefore, ClpC may provide links between the competence pathway and the stress response. Originally, the $m e c A$ and $m e c B$ mutations were isolated as allowing competence gene expression in complex media (Dubnau \& Roggiani, 1990). Interaction of $\mathrm{MecB}$ with MecA 
negatively regulates the synthesis of ComK, a transcriptional activator required for the expression of late competence genes (Kong \& Dubnau, 1994; Msadek et al., 1994). Expression of the $c l p C$ gene, encoding the general stress protein GSP12, was previously shown to be induced by various stress conditions (Krüger et al., 1994). The nucleotide sequence of a $180 \mathrm{~kb}$ region containing $c l p C$ was reported as part of the B. subtilis genome sequencing project, suggesting that $c l p C$ is the fourth gene of an operon containing six open reading frames (Ogasawara et al., 1994). We recently showed that the six genes are cotranscribed as an operon, preceded by two promoters. One resembles promoters recognized by the vegetative RNA polymerase $\mathrm{E} \sigma^{\mathrm{A}}$. The other promoter was shown to be stress-inducible and dependent upon $\sigma^{\mathrm{B}}$, the general stress $\sigma$-factor in $B$. subtilis (Haldenwang, 1995). However, in a sigB mutant, the $\sigma^{\mathrm{A}}$-like promoter became inducible, completely compensating for $\sigma^{\mathrm{B}}$ deficiency (Krüger et al., 1996). Even in the absence of $\sigma^{\mathrm{B}}$ this promoter switch ensures a similar rate of protein synthesis as in the wild-type. In addition, we found conditions which exclusively induce the vegetative $\sigma^{\mathrm{A}}$ promoter such as amino acid limitation or hydrogen peroxide (Krüger et al., 1996).

Two genes of the $c l p C$ operon, orf 3 and orf5, were cloned previously and designated orf $X$ and orf $Y$ (Msadek et al., 1994). Orf5 shares significant similarities with the Escherichia coli sms gene product (sensitivity to methyl methanesulfonate; Neuwald et al., 1994). Potential functions of the orf5 and orf6 gene products encoded by this operon were investigated in this study.

\section{METHODS}

Bacterial strains, plasmids and culture conditions. Bacterial strains are listed in Table 1. E. coli strains DH5 $\alpha$ and RR1 were routinely grown in LB medium and used as hosts for DNA manipulation. B. subtilis was cultivated with vigorous aeration at $37^{\circ} \mathrm{C}$ in LB medium or a previously described synthetic medium (Stülke et al., 1993). Media were supplemented with the following antibiotics when necessary: ampicillin $\left(100 \mu \mathrm{g} \mathrm{ml}^{-1}\right)$, chloramphenicol $\left(5 \mu \mathrm{g} \mathrm{ml}^{-1}\right)$, spectinomycin $\left(100 \mu \mathrm{g} \mathrm{ml}^{-1}\right)$, or erythromycin $\left(1 \mu \mathrm{g} \mathrm{ml}^{-1}\right)$ plus lincomycin $\left(25 \mu \mathrm{g} \mathrm{ml}^{-1}\right)$. The SPAC promoter (Pspac) (Yansura \& Henner, 1984) was induced by treatment with $1 \mathrm{mM}$ IPTG.

Sensitivity to methyl methanesulfonate (MMS) was tested according to Neuwald et al. (1992) by growing the cells in LB into the exponential growth phase and plating them in soft agar onto LB plates. A paper disc with $10 \mu \mathrm{l}$ MMS was placed in the centre of the plate, giving a final concentration of $0.05 \%$ MMS. To investigate survival after UV-irradiation, appropriate dilutions of cells from the exponential phase, the transition phase or the stationary phase were plated onto LB agar and exposed to UV light for $10 \mathrm{~s}\left(8 \mathrm{~W} \mathrm{~cm} \mathrm{~cm}^{-2}, 312 \mathrm{~nm}\right.$, Vilbert Lourmat transilluminator) and incubated overnight at $37^{\circ} \mathrm{C}$. The distance between the agar surface and the UV source was $1 \mathrm{~cm}$.

General methods. Plasmid isolation, restriction enzyme analysis, transformation of $E$. coli, ligation of DNA fragments and filling in the recessed 3 ' termini using the Klenow fragment of DNA polymerase I were performed according to standard protocols (Sambrook et al., 1989). Recombinant plasmids were sequenced by the dideoxy chain-termination method of Sanger et al. (1977). DNA fragments were amplified by PCR as described earlier (Krüger et al., 1994). Some oligonucleotides used for PCR included mismatches allowing creation of EcoRI and BamHI restriction sites. Chromosomal DNA from $B$. subtilis was isolated as described by Msadek et al. (1991). Transformation of $B$. subtilis with plasmid or chromosomal DNA was carried out using a two-step protocol (Hoch, 1991).

Construction of plasmids for generating orf5 and orf 6 mutant strains. pMEC32 was constructed by deleting a $1826 \mathrm{bp}$ HindIII fragment from pMEC28 (Msadek et al., 1994), removing the last 111 codons of orf 3 and the first 497 codons of $c l p C$. A 1238 bp Smal fragment carrying the spectinomycin resistance gene from Staphylococcus aureus (Murphy, 1985) was then cloned into the unique PstI site within orf5 (codon 109 ) in plasmid pMEC32, to give pMEC39. Plasmid pMEC39 was linearized by EcoRI digestion and transformed into $B$. subtilis, selecting for spectinomycin resistance, indicating a double crossover event (strain BEK9). To exclude transformants carrying the mutation as a Campbell-type integration, spectinomycin-resistant transformants were tested for erythromycin sensitivity.

The orf5 disruption in strain BEK9 was verified by PCR using chromosomal DNA of the transformant as a template. Strain BEO1 was constructed by cloning the $531 \mathrm{bp} \mathrm{ScaI-BamHI}$ orf5 fragment of pMEC28 into pDH88 (Henner, 1990) and transforming IS58 with the resulting plasmid pDSMS. In strain BEO1 orf5 is disrupted by a single crossover recombination event allowing reinitiation of transcription by Pspac downstream of orf5.

pMEC60 was constructed by cloning a 200 bp BamHI PCR fragment internal to orf6 using oligonucleotides TM-116 $\left(5^{\prime}\right.$ GGAGGATCCGATGCCGGATGCCACAATTTC-3') and TM-117 (5'-GGAGGATCCAGTGTTTGAATGGCTTGGTTC-3') into plasmid pHT181 (Lereclus \& Arantes, 1993). When integrated by a Campbell-type event, this internal fragment gave rise to two truncated copies of orf6 (strain BEK60). All Campbell-type disruptions were verified by Southern-blot analysis using digoxigenin-labelled PCR fragments as probes according to the manufacturer's recommendation (Boehringer Mannheim).

\section{RESULTS}

\section{Predicted protein sequence analysis}

The predicted amino acid sequences of the five other open reading frames cotranscribed with $c l p C$ (Fig. 1) were compared with the GenBank database using the BLAST (Altschul et al., 1990) network service at the National Center for Biotechnology Information, with the default parameter values provided. Only matches with a probability lower than $\mathrm{e}^{-7}$ were considered significant, except in cases noted below.

A chromosomal locus of the facultative pathogen Listeria monocytogenes was identified recently, displaying a genetic organization similar to that of the $c l p C$ locus in B. subtilis (Rouquette et al., 1996). Strong similarities were noted between Orf1, Orf2, Orf3, ClpC and Orf5 of B. subtilis and L. monocytogenes, with amino acid sequence identities of $64 \%, 29 \%, 50 \%$, $73 \%$ and $70 \%$, respectively (Rouquette et al., 1996). 
Table 1. Strains and plasmids used in this study

\begin{tabular}{|c|c|c|}
\hline Strain/plasmid & Relevant genotype & Source/reference \\
\hline \multicolumn{3}{|l|}{ E. coli } \\
\hline RR1 & $\begin{array}{l}\mathrm{F}^{-} \text {mcrB mrr hsdS20 }\left(\mathrm{r}_{\mathrm{B}}^{-} \mathrm{m}_{\mathrm{B}}^{-}\right) \text {ara-14 proA2 lacY1 leu galK2 rpsL20 }\left(\mathrm{Sm}^{\mathrm{r}}\right) \\
x y l 5 \text { mtl-1 supE44 }\end{array}$ & Bolivar et al. (1977) \\
\hline $\mathrm{DH} 5 \alpha$ & $\begin{array}{l}\mathrm{F}^{-} \phi 80 \mathrm{~d} l a c Z \Delta \mathrm{M} 15 \Delta(\operatorname{lac} Z Y A-a r g F) U 169 \text { deoR recA1 endA1 hsdR17 } \\
\left(\mathrm{r}_{\mathrm{K}}^{-} \mathrm{m}_{\mathrm{K}}^{+}\right) \text {supE44 thi-1 gyrA96 }\end{array}$ & Hanahan (1985) \\
\hline \multicolumn{3}{|l|}{ B. subtilis } \\
\hline IS58 & $\operatorname{trp} C 2$ lys-3 & Smith et al. (1980) \\
\hline BEO1 & $\operatorname{trpC2}$ lys-3 sms: :pDH88 & pDSMS $\rightarrow$ IS 58 \\
\hline BEK9 & $\operatorname{trp} C 2$ lys-3 sms: :spc & pMEC39 $\rightarrow$ IS58 \\
\hline BEK56 & $\operatorname{trp} C 2$ lys-3 amyE: : (orf1-'lacZ aphA3) & Krüger et al. (1996) \\
\hline BEK60 & $\operatorname{trpC} 2$ lys-3 orf6: : pHT181 & $\mathrm{pMEC} 60 \rightarrow \mathrm{IS} 58$ \\
\hline \multicolumn{3}{|l|}{ Plasmids } \\
\hline $\mathrm{pAC7}$ & $\mathrm{Ap}^{\mathrm{r}} \mathrm{Km}^{\mathrm{r}} \operatorname{lac} \mathrm{Z}$ & Krüger et al. (1996) \\
\hline pDH88 & $\mathrm{Ap}^{\mathrm{r}} \mathrm{Cm}^{\mathrm{r}} \mathrm{P} s p a c$ & Henner (1990) \\
\hline pHT181 & $\mathrm{Ap}^{\mathrm{r}} \mathrm{Em}^{\mathrm{r}}$ & Lereclus \& Arantes (1993) \\
\hline pWH331 & $\mathrm{Neo}^{r} \mathrm{Cm}^{r}$ & Gärtner et al. (1988) \\
\hline pSPEC & $\mathrm{Ap}^{\mathrm{r}} \mathrm{Spc}^{\mathrm{r}}$ & P. Trieu-Cuot, unpublished \\
\hline pDSMS & pDH88 derivative with a $531 \mathrm{bp}$ fragment of orf 5 & This work \\
\hline pMEC28 & $\begin{array}{l}\mathrm{Ap}^{\mathrm{r}} \mathrm{Em}^{\mathrm{r}} \text { E. coli/B. subtilis shuttle vector containing part of } \text { orf } 3, \operatorname{clp} C \text { and } \\
\text { part of orf5 }\end{array}$ & Msadek et al. (1994) \\
\hline pMEC32 & pMEC28 derivative constructed by deleting a 1826 bp HindIII fragment & This work \\
\hline pMEC39 & $\begin{array}{l}\text { pMEC32 derivative carrying the spectinomycin resistance gene in the } \\
\text { unique PstI site }\end{array}$ & This work \\
\hline pMEC60 & $\begin{array}{l}\text { pHT181 derivative containing a } 200 \text { bp Bam HI PCR fragment internal to } \\
\text { orf6 }\end{array}$ & This work \\
\hline
\end{tabular}

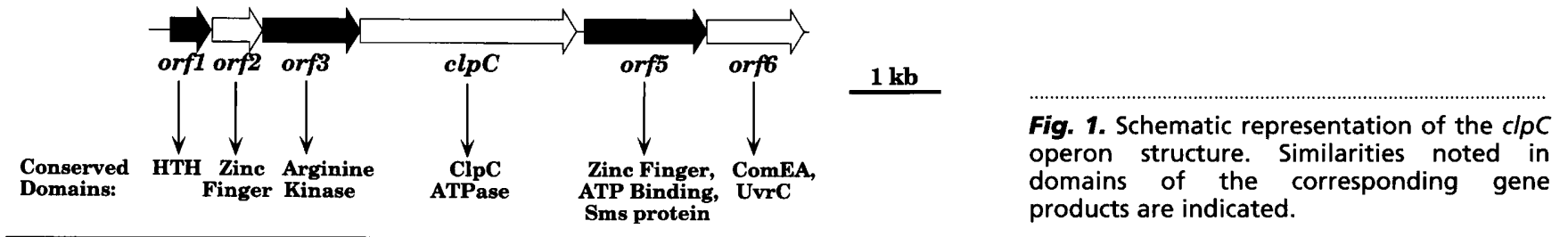

However, an equivalent of orf6 of B. subtilis is not present in the reported $L$. monocytogenes nucleotide sequence (GenBank accession number U40604), where instead orf 5 is followed by an open reading frame whose product shows similarities with that of a gene lying downstream from orf6 in B. subtilis. Except for ClpC, no functional role has been established for the products of orf1, 2, 3 and 5 in L. monocytogenes (Rouquette et al., 1996).

The product of orf1 (154 aa) of the B. subtilis clpC operon displays no significant similarities to proteins in the database. However, a predicted helix-turn-helix DNA-binding motif was detected in Orf1 using the weight matrix of Dodd \& Egan (1990), beginning at amino acid 29 (RSEIADKFQCVPSQINYVIN, SD score $4 \cdot 12$. HTH probability $>90 \%$ ). This suggests that Orf1 may have a regulatory role. Interestingly, this potential helix-turn-helix domain is highly conserved in the orf1 product of L. monocytogenes.
Similarities between Orf2 (185 aa) of B. subtilis and proteins in the database were noted with a large family of eukaryotic regulatory proteins, characterized by a zinc-finger nucleic-acid-binding domain (Klug \& Rhodes, 1987; Vallee et al., 1991). Indeed, Orf2 contains two potential $\mathrm{Cys}_{2}-\mathrm{Cys}_{2}$ zinc-finger motifs, at positions $\mathrm{C}_{3}-\mathrm{C}_{6}$ to $\mathrm{C}_{29}-\mathrm{C}_{32}$ and $\mathrm{C}_{81}-\mathrm{C}_{84}$ to $\mathrm{C}_{99}-\mathrm{C}_{102}$.

orf 3 encodes a putative protein (363 aa) with a domain that is highly conserved among ATP:guanidino phosphotransferases such as arginine kinases (e.g. Homarus vulgaris; Dumas \& Camonis, 1993) or creatine kinases (e.g. Schistosoma mansoni; Stein et al., 1990). This domain extends from amino acids 119 to 251 of Orf3, presenting $35 \%$ sequence identity on average with members of this family of kinases.

As previously reported (Msadek et al., 1994; Ogasawara et al., 1994), the deduced amino acid sequence of orf5 ( 458 aa) shows $46 \%$ identity with that of the E. colisms gene, whose absence confers sensitivity to MMS 


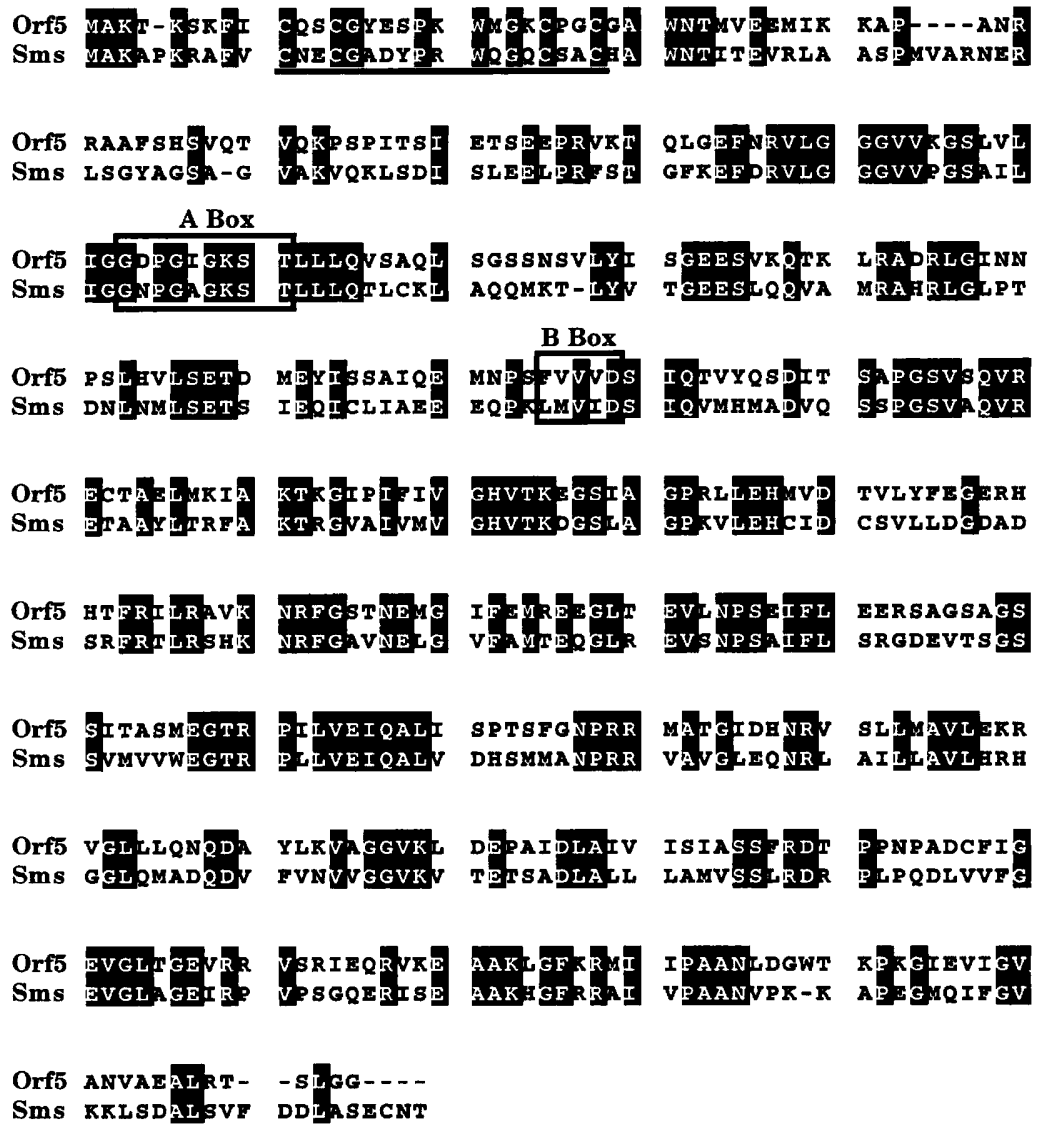

(Neuwald et al., 1992) (Fig. 2). The orf5 and sms gene products both contain conserved ATP-binding A and B motifs (Walker et al., 1982) as well as a potential zincfinger nucleic-acid-binding domain (positions $\mathrm{C}_{10}-\mathrm{C}_{13}$ to $\mathrm{C}_{24}-\mathrm{C}_{27}$, Fig. 2). The sms gene appears to be highly conserved among prokaryotes and is also present in Salmonella typhimurium, Haemophilus influenzae and Synechocystis sp. Sms proteins also show similarities with RecA, in the vicinity of the ATP-binding site, and the carboxy-terminal region shows similarities with Lon proteases (Neuwald et al., 1992).

Although the potential orf6 gene product (360 aa, formerly orf360; Ogasawara et al., 1994) shows no strong sequence similarities with proteins in the database, we noted some slight similarities with several proteins that interact with nucleic acids, such as DNA ligase of Thermus thermophilus and ATP-dependent RNA helicase of Methanococcus jannaschii. Indeed, a short carboxy-terminal region of Orf6 (amino acids 300-358) shows approximately 30\% sequence identity with a corresponding stretch in these proteins as well as the E. coli UvrC DNA repair excinuclease (Sancar et al., 1984) and ComEA of B. subtilis (Inamine \& Dubnau, 1995).

Hydropathy profiles of the products of the six genes in the $c l p C$ operon, determined by the method of Kyte \& Doolittle (1982), suggested that these proteins are all
Fig. 2. Alignment of the $B$. subtilis Orf5 amino acid sequence with that of the $E$. coli sms gene product (Neuwald et al., 1992). Identical residues are shaded. ATP-binding A and B motifs (Walker et al., 1982) are boxed, and a potential zinc-finger nucleic-acidbinding domain is underlined. cytoplasmic since no significantly hydrophobic potential transmembrane regions were noted (cutoff value: $2 \cdot 6$ ).

\section{The sms phenotype of an orf5 mutant}

As indicated above, the deduced product of the fifth open reading frame shows about $50 \%$ amino acid sequence identity with the E. coli sms gene product. The orf5 gene was disrupted, generating mutant BEK9.

To examine the possibility that orf5 is indeed an sms homologue in B. subtilis, sensitivity to the alkylating agent MMS was tested using a paper disc method as described by Neuwald et al. (1990). Several independent experiments were performed by plating exponentially growing cultures of the BEK9 (orf5) and BEK60 (orf6) mutants in parallel with the corresponding wild-type strain IS58 on agar plates with a paper disc containing MMS (see Methods). Diameters of clear inhibition zones were measured. For a given strain, the diameters varied by less than $\pm 2 \mathrm{~mm}$. Treatment with MMS $(0.05 \%)$ resulted in average inhibition zones that were reproducibly larger in diameter for the mutant strain BEK9 (46 mm) than for the wild-type strain $(40 \mathrm{~mm})$, which is comparable to results obtained with the E. coli sms mutant. Strain BEK60 gave results nearly identical to the wild-type. These results suggest that a mutation in orf5 leads to increased sensitivity of the mutant cells to 
Table 2. Survival after UV-irradiation of $B$. subtilis wild-type strain in comparison to orf5 and orf6 mutants in different growth phases in competence medium

\begin{tabular}{|c|c|c|c|}
\hline \multirow[t]{2}{*}{ Growth phase } & \multicolumn{3}{|c|}{ Survival of ${ }^{*}:$} \\
\hline & Wild-type IS58 & orf 5 mutant BEO1 $\dagger$ & orf6 mutant BEK60 \\
\hline Exponential $\left(\mathrm{OD}_{500} 0 \cdot 4\right)$ & $\begin{array}{r}1.3 \times 10^{-2} \\
\left( \pm 0.32 \times 10^{-2}\right)\end{array}$ & $\begin{array}{r}0.9 \times 10^{-2} \quad[69.2 \%] \\
\left( \pm 0.28 \times 10^{-2}\right)\end{array}$ & $\begin{aligned} & 1.1 \times 10^{-2} \quad[84.6 \%] \\
\left( \pm 0.31 \times 10^{-2}\right) & \end{aligned}$ \\
\hline Transition $\left(\mathrm{OD}_{500} 1 \cdot 0\right)$ & $\begin{array}{r}7 \cdot 1 \times 10^{-2} \\
\left( \pm 1 \cdot 0 \times 10^{-2}\right)\end{array}$ & $\begin{array}{c}1.04 \times 10^{-2} \quad[14.6 \%] \\
\left( \pm 0.5 \times 10^{-2}\right)\end{array}$ & $\begin{array}{l}1.25 \times 10^{-2} \quad[17.6 \%] \\
\left( \pm 0.6 \times 10^{-2}\right)\end{array}$ \\
\hline Stationary $\left(\mathrm{OD}_{\tilde{5} 00} 1 \cdot 3\right)$ & $\begin{array}{r}4.95 \times 10^{-2} \\
\left( \pm 1.0 \times 10^{-2}\right)\end{array}$ & $\begin{array}{r}0.9 \times 10^{-2} \quad[18.2 \%] \\
\left( \pm 0.15 \times 10^{-2}\right)\end{array}$ & $\begin{array}{c}1.02 \times 10^{-2} \quad[20.6 \%] \\
\left( \pm 0.5 \times 10^{-2}\right)\end{array}$ \\
\hline
\end{tabular}

* Survival after UV-irradiation is indicated as the ratio of colony-forming units with and without UV treatment. Means of five independent experiments are shown, with standard deviations indicated in parentheses. For the orf 5 and orf6 mutants, percentage survival in comparison to the wild-type is shown in square brackets.

†Cells of strain BEO1 were cultivated with the addition of $1 \mathrm{mM}$ IPTG to induce Pspac.

MMS, as described for E. coli. We therefore propose that orf5 be designated sms.

\section{Survival of orf5 and orf6 mutants after UV-irradiation}

Stationary-phase cells of $E$. coli are more resistant to UV-irradiation than exponentially growing cells, in a $\sigma^{\mathrm{s}}$ dependent manner (for a review see Hennge-Aronis, 1993). Functional similarities between the $\sigma^{\mathrm{S}}$ regulon in $E$. coli and the $\sigma^{\mathrm{B}}$ regulon in $B$. subtilis have been described for the katE gene (Engelmann et al., 1995; Engelmann \& Hecker, 1996). Furthermore, the clpC operon is partly $\sigma^{\mathrm{B}}$-dependent.

To investigate the UV survival response of mutants affected in the $c l p C$ operon, we first examined the survival of B. subtilis wild-type IS58 cells following exposure to UV-irradiation at different growth phases in glucose limitation medium (GLM) and under amino acid limitation (competence medium; CM). Samples were taken during exponential growth at an $\mathrm{OD}_{500}$ of 0.4 , in the transition phase $\left(\mathrm{OD}_{500} 0.8\right.$ for GLM; $\mathrm{OD}_{500} 1.0$ for $\mathrm{CM}$ ) or $1 \mathrm{~h}$ after entry into stationary phase $\left(\mathrm{OD}_{500} 1.0\right.$ for GLM; OD 5001.3 for CM). Only amino-acid-starved cells showed an approximately fivefold increased resistance to UV-irradiation; glucosestarved cells showed no increase in resistance (data not shown). Therefore, competence medium was used for further experiments.

Since Orf5 and Orf6 have similarities with DNA-repair enzymes, we investigated mutants in both genes for survival after UV-irradiation. To avoid polar effects of the insertional mutation within orf5 another mutant was constructed using plasmid pDSMS, allowing reinitiation of transcription by Pspac. This mutant, BEO1, also shows the $s m s$ phenotype. In all experiments IPTG was added to the culture of strain BEO1 to a final concentration of $1 \mathrm{mM}$. Several independent UVirradiation experiments were performed, resulting in approximately $1 \%$ survival for the wild-type during the exponential growth phase. However, the number of viable wild-type cells increased to $7 \%$ and $5 \%$ during the transition and stationary phases, respectively. Setting survival of the wild-type to $100 \%$, only $15-20 \%$ of the mutants BEO1 and BEK60 cells survived this procedure in transition and stationary phase, whereas in the exponential growth phase the sensitivity of the mutants was less pronounced (Table 2). These results suggest the involvement of Orf5 as well as Orf6 in the development of a non-specific stationary-phase resistance to UV-irradiation of amino-acid-starved B. subtilis cells. Results obtained with the orf5 mutant BEK9 after UV-irradiation were similar to those with the BEO1 mutant, indicating that polar effects do not play a role (data not shown).

\section{Orf5 and Orf6 are involved in genetic competence}

We had previously noted that a $c l p C$ deletion mutant showed a decrease in transformability compared to a mutant with a point mutation in $c l p C$ (T. Msadek, unpublished). Given the slight similarities of the carboxy-terminal domain of Orf6 with ComEA, which is essential for competence development in B. subtilis, we investigated the possible role of Orf6 in competence. Since the SOS response and the development of genetic competence overlap (Cheo et al., 1993), it was interesting to test whether competence is also influenced in an orf5 mutant. Transformation experiments were carried out by preparing competent cells of strains BEO1, BEK60 and the corresponding wild-type strain IS58 in parallel. Cells were transformed with the replicative plasmid pWH331 (Gärtner et al., 1988), with pAC7, a plasmid which cannot replicate in $B$. subtilis but integrates via a single crossover event in the amyE locus, or with chromosomal DNA of strain BEK56 requiring a double crossover event (Krüger et al., 1996), with selection for the corresponding antibiotic resistance. Transformation 
Table 3. Transformability of orf5 and orf6 mutants in comparison to the wild-type

\begin{tabular}{|lccc|}
\hline DNA type & \multicolumn{3}{c|}{ Frequency of transformation (\%)* } \\
\cline { 2 - 4 } & Wild-type IS58 & orf5 mutant BEO1† & orf6 mutant BEK60 \\
\hline Replicating plasmid (pWH331) & 0.81 & $0.58(1 \cdot 4 \times)$ & $0 \cdot 18 \times 10^{-1}(45 \times)$ \\
Non-replicating plasmid (pAC7) & $0 \cdot 12$ & $0.52 \times 10^{-2}(23 \times)$ & $0.32 \times 10^{-2}(37 \times)$ \\
single crossover & $0 \cdot 18$ & $0.49 \times 10^{-2}(37 \times)$ & $0.51 \times 10^{-2}(35 \times)$ \\
Chromosomal (BEK56) & 0.18 & \\
\hline
\end{tabular}

*Frequency of transformation is indicated as (kanamycin-resistant transformants/viable cells) $\times 100$. The means of four independent experiments are shown; standard deviations were less than $10 \%$ of the mean. The numbers in parentheses indicate $x$-fold decrease of transformation frequency of the mutant strains in comparison to the wild-type.

†Cells of strain BEO1 were cultivated with the addition of $1 \mathrm{mM}$ IPTG to induce Pspac.

experiments are summarized in Table 3 . Transformation with a replicative plasmid was not strongly influenced in the sms mutant BEO1 in comparison to the wild-type. However, transformation rates dropped significantly with chromosomal DNA, requiring recombination events. The orf6 disruption led to a strong decrease of competence in every case, indicating that orf6 might be a novel competence gene. We therefore suggest that orf6 be renamed com Y.

\section{DISCUSSION}

To study the functions of the other five unknown gene products encoded by the $c l p C$ operon, database analysis was performed and phenotypes of selected mutants were investigated. The high probability of a helix-turn-helix motif within the amino acid sequence of Orf1 suggests a possible regulatory role for this protein. Preliminary results of our group indeed show that Orf1 may act as a repressor of the $c l p C$ operon expression under non-stressed conditions (E. Krüger \& $M$. Hecker, unpublished).

For the fifth gene, orf5, whose product is similar to that of the E. coli sms gene (Neuwald et al., 1992), similar phenotypes were observed for the mutant, leading to mild sensitivity to the alkylating agent MMS during exponential growth phase. Hence, the gene product may participate in repair of DNA damage by alkylation or DNA repair in general. This assumption is underlined by the increased sensitivity of sms (orf5) mutants to UVirradiation. The increased sensitivity was also observed for mutants in orf6, suggesting that Orf6, which shows some weak similarities to nucleases, is also involved in DNA repair. Recently, we found that a $\sigma^{\mathrm{B}}$ - and a presumably $\sigma^{\mathrm{A}}$-dependent promoter direct stressinduced transcription of the $c l p C$ operon. Expression from the $\sigma^{\mathrm{A}}$-like promoter alone could be induced in response to stress conditions that do not induce $\sigma^{\mathrm{B}}$, such as hydrogen peroxide treatment or amino acid starvation (Krüger et al., 1996). Increased stationary-phase resistance to UV-irradiation was shown for amino-acidstarved but not for glucose-starved cells, indicating that this phenomenon is mediated by a $\sigma^{\mathrm{B}}$-independent mechanism. Our results suggest that $\mathrm{Sms}$ (Orf5) as well as ComY (Orf6) are involved in this mechanism, emphasizing an important function for $\sigma^{\mathbf{A}}$-dependent induction of the $c l p C$ operon. However, the function of both Sms (Orf5) and ComY (Orf6) might only be important for the development of a non-specific stationary-phase resistance to UV-irradiation in addition to the constitutive excision and recombination repair systems involving the recA and the uvrA loci (Friedman \& Yasbin, 1983).

Disruption of the sixth open reading frame, orf6, resulted in a significant decrease in competence for DNA transformation. Although there is no indication of the membrane association of Orf6, according to the hydropathy calculation method of Kyte \& Doolittle (1982), one cannot exclude a role for this protein in DNA uptake, as observed for mutants in the comEA locus (Albano et al., 1987; Hahn et al., 1993; Inamine \& Dubnau, 1995). An sms (orf5) mutation led to decreased transformability with DNA requiring homologous recombination. In view of the results discussed above and the inducibility of the $c l p C$ operon by DNA-damageinducing treatment with hydrogen peroxide (Krüger et al., 1996), an involvement of the sms and comY (orf5 and orf6) gene products in either DNA-damage repair or competence, or both, could explain the phenotypes of these mutants. The link between the two mechanisms is an apparent overlap in the regulatory mode of the competence-dependent induction of the SOS system and the regulation of the competence regulon itself (Cheo et al., 1993). However, previous data suggest that mutations in the regulatory genes of the competence pathway do not significantly affect vegetative-phase expression of a clpC-lacZ fusion (Msadek et al., 1994). Furthermore, the consensus sequence found upstream of DNA-damage-inducible genes (GAAC- ${ }_{4}$-GTTC; Cheo et al., 1993) is not present in the $c l p C$ operon. This suggests that DNA-damage induction of the $c l p C$ operon may involve a different mechanism from that of the din regulon. Protection of DNA or proteins against stress damage is essential for bacteria to keep existing cellular structures in a functional state. B. subtilis has developed efficient systems for detoxification and repair of DNA 
under stress conditions. Interestingly, these include $\sigma^{\mathrm{B}}$ dependent and $\sigma^{\mathrm{B}}$-independent general stress proteins. The $\mathrm{H}_{2} \mathrm{O}_{2}$-inducible genes $k a t A$ and $\operatorname{mrg} A$, the $\operatorname{din}$ genes, the alkyl hydroperoxide reductase operon $a h p C / a b p F$ and the superoxide dismutase gene sod encode enzymes responsible for a specific oxidative stress resistance (Antelmann et al., 1996; Bol \& Yasbin, 1994; Cheo et al., 1993; Chen et al., 1995). However, genes of the $\sigma^{\mathrm{B}}$ regulon of $B$. subtilis seem to encode proteins that provide a non-specific protection of the cell against oxidative stress during starvation (Engelmann \& Hecker, 1996). Our results suggest that Sms and ComY (Orf5 and Orf6) might belong to such nonspecific systems. In this context, an overlap between the $\sigma^{\mathrm{B}}$-dependent and $\sigma^{\mathrm{B}}$-independent general stress responses, the SOS response and competence for DNA transformation seems plausible.

\section{ACKNOWLEDGEMENTS}

We thank Uwe Völker for critical reading of the manuscript and P. Trieu-Cuot for plasmid pSPEC. Susanne Engelmann is acknowledged for helpful discussions on oxidative stress response. Furthermore, we are grateful to Georges Rapoport in whose laboratory part of this work was carried out.

This work was supported by grants from the Deutsche Forschungsgemeinschaft and the Fonds der Chemischen Industrie to M.H.

\section{REFERENCES}

Albano, M., Hahn, J. \& Dubnau, D. (1987). Expression of competence genes in Bacillus subtilis. J Bacteriol 169, 3110-3117. Altschul, S. F., Gish, W., Miller, W., Myers, E. W. \& Lipman, D. J. (1990). Basic local alignment search tool. J Mol Biol 215, 403-410.

Antelmann, H., Engelmann, S., Schmid, R. \& Hecker, M. (1996). General and oxidative stress responses in Bacillus subtilis: cloning, expression, and mutation of the alkyl hydroperoxide reductase operon. J Bacteriol 178, 6571-6578.

Bol, D. \& Yasbin, R. (1994). Analysis of the dual regulatory mechanisms controlling expression of the vegetative catalase gene of Bacillus subtilis. J Bacteriol 175, 6744-6748.

Bolivar, F., Rodrigues, R. L., Greener, P. J., Betlach, M. C., Heyneker, H. L., Boyer, H. W., Crosa, J. H. \& Falkow, S. (1977). Construction and characterization of new cloning vehicles. II. A multipurpose cloning system. Gene 2, 95-133.

Bukau, B. (1993). Regulation of the Escherichia coli heat shock response. Mol Microbiol 9, 671-680.

Chen, L., Keramati, L. \& Hellman, J.D. (1995). Coordinate regulation of Bacillus subtilis peroxide stress genes by hydrogen peroxide and metal ions. Proc Natl Acad Sci USA 92, 8190-8194.

Cheo, D. L., Bayles, K. W. \& Yasbin, R. E. (1993). Elucidation of regulatory elements that control damage induction and competence induction of the Bacillus subtilis SOS system. J Bacteriol 175, 5907-5915.

Dodd, I. B. \& Egan, J. B. (1990). Improved detection of helixturn-helix DNA-binding motifs in protein sequences. Nucleic Acids Res 18, 5019-5026.

Dubnau, D. (1991). Genetic competence in Bacillus subtilis. Microbiol Rev 55, 395-424.

Dubnau, D. \& Roggiani, M. (1990). Growth medium-independent genetic competence mutants of Bacillus subtilis. J Bacteriol 172, 4048-4055.

Dubnau, D., Hahn, J., Roggiani, M., Piazza, F. \& Weihrauch, Y. (1994). Two-component regulators and genetic competence in Bacillus subtilis. Res Microbiol 145, 403-411.

Dumas, C. \& Camonis, J. (1993). Cloning and sequence analysis of the cDNA for arginine kinase of lobster muscle. J Biol Chem $\mathbf{2 6 8}$, 21599-21605.

Engelmann, S. \& Hecker, M. (1996). Impaired oxidative stress resistance of Bacillus subtilis sigB mutants and the role of katA and katE. FEMS Microbiol Lett 145, 63-69.

Engelmann, S., Lindner, C. \& Hecker, M. (1995). Cloning, nucleotide sequence, and regulation of katE encoding a $\sigma^{\mathrm{B}}$ dependent catalase in Bacillus subtilis. J Bacteriol 177, 5598-5605.

Friedman, B. M. \& Yasbin, R. E. (1983). The genetics and specificity of the constitutive excision repair system of Bacillus subtilis. Mol Gen Genet 190, 481-486.

Gärtner, D., Geißendörfer, M. \& Hillen, W. (1988). Expression of the $B$. subtilis $x y l$ operons repressed at the level of transcription and is induced by xylose. J Bacteriol 170, 3102-3109.

Hahn, J., Inamine, G., Kozlov, Y. \& Dubnau, D. (1993). Characterization of comE, a late competence operon of Bacillus subtilis required for the binding and uptake of transforming DNA. Mol Microbiol 10, 99-111.

Haldenwang, W. G. (1995). The sigma factors of Bacillus subtilis. Microbiol Rev 59, 1-30.

Hanahan, D. (1985). Techniques for transformation of Escherichia coli. In DNA Cloning: a Practical Approach, vol. 1, pp. 109-135. Edited by D. M. Glover. Oxford: IRL Press.

Hecker, M., Schumann, W. \& Völker, U. (1996). Heat shock and general stress response in Bacillus subtilis. Mol Microbiol 19, $417-428$.

Hengge-Aronis, R. (1993). Survival of hunger and stress: the role of $r p o S$ in early stationary phase gene regulation in E. coli $\mathrm{K} 12$. Cell 72, 165-168.

Henner, D. J. (1990). Inducible expression of regulatory genes in Bacillus subtilis. Methods Enzymol 185, 223-228.

Hoch, J. A. (1991). Genetic analysis in Bacillus subtilis. Methods Enzymol 204, 305-320.

Inamine, G. S. \& Dubnau, D. (1995). ComEA, a Bacillus subtilis integral membrane protein required for genetic transformation, is needed for both DNA binding and transport. J Bacteriol 177, 3045-3051.

Klug, A. \& Rhodes, D. (1987). 'Zinc fingers': a novel protein motif for nucleic acid recognition. Trends Biochem Sci 12, 464-469.

Kong, L. \& Dubnau, D. (1994). Regulation of competence-specific gene expression by Mec-mediated protein-protein interaction in Bacillus subtilis. Proc Natl Acad Sci USA 91, 5793-5797.

Krüger, E., Völker, U. \& Hecker, M. (1994). Stress induction of $c l p C$ in Bacillus subtilis and its involvement in stress tolerance. $J$ Bacteriol 176, 3360-3367.

Krüger, E., Msadek, T. \& Hecker, M. (1996). Alternate promoters direct stress induced transcription of the Bacillus subtilis clpC operon. Mol Microbiol 20, 713-723.

Kyte, J. \& Doolittle, R. F. (1982). A simple method for displaying the hydropathic character of a protein. J Mol Biol 157, 105-132.

Lereclus, D. \& Arantes, O. (1992). $s p b A$ locus ensures the segregational stability of pHT1030, a novel type of Gram-positive replicon. Mol Microbiol 6, 35-46.

Msadek, T., Kunst, F., Klier, A. \& Rapoport, G. (1991). DegS-DegU 
and ComP-ComA modulator-effector pairs control expression of the Bacillus subtilis pleiotropic regulatory gene degQ. J Bacteriol 173, 2366-2377.

Msadek, T., Kunst, F. \& Rapoport, G. (1994). MecB of Bacillus subtilis, a member of the ClpC ATPase family, is a pleiotropic regulator controlling competence gene expression and survival at high temperature. Proc Natl Acad Sci USA 91, 5788-5792.

Msadek, T., Kunst, F. \& Rapoport, G. (1995). A signal transduction network in Bacillus subtilis includes the DegS/DegU and ComP/ ComA two-component systems. In Two-component Signal Transduction, pp. 447-471. Edited by J. A. Hoch \& T. J. Silhavy. Washington, DC: American Society for Microbiology.

Murphy, E. (1985). Nucleotide sequence of a spectinomycin adenyl transferase $\mathrm{AAD}(9)$ determinant from Staphylococcus aureus and its relationship to $\operatorname{AAD}\left(3^{\prime \prime}\right)(9)$. Mol Gen Genet 200, 33-39.

Neuwald, A. F., Berg, D. E. \& Stauffer, G. V. (1992). Mutational analysis of the Escherichia coli serB promoter region reveals transcriptional linkage to a downstream gene. Gene 120, 1-9.

Ogasawara, N., Nakai, S. \& Yoshikawa, H. (1994). Systematic sequencing of the 180 kilobases region of the Bacillus subtilis chromosome containing the replication origin. DNA Res 1,1-14.

Rouquette, C., Ripio, M.-T., Pellegrini, E., Bolla, J.-M., Tascon, R. I., Vázquez-Boland, J.-A. \& Berche, P. (1996). Identification of a ClpC ATPase required for stress tolerance and in vivo survival of Listeria monocytogenes. Mol Microbiol 21, 977-987.

Sambrook, J., Fritsch, E. F. \& Maniatis, T. (1989). Molecular Cloning: a Laboratory Manual, 2nd edn. Cold Spring Harbor, NY: Cold Spring Harbor Laboratory.
Sancar, G. B., Sancar, A. \& Rupp, W. D. (1984). Sequence of the E. coli uvrC gene and protein. Nucleic Acids Res 12, 4593-4608.

Sanger, F. S., Nicklen, S. \& Coulson, A. R. (1977). DNA sequencing with chain-terminating inhibitors. Proc Natl Acad Sci USA 74, 5463-5467.

Smith, I., Paress, P., Cabane, K. \& Dubnau, E. (1980). Genetics and physiology of the rel system of Bacillus subtilis. Mol Gen Genet 178, 271-279.

Stein, L. D., Harn, D. A. \& David, J. R. (1990). A cloned ATP:guanidino kinase in the trematode Schistosoma mansoni has a novel duplicated structure. J Biol Chem 265, 6582-6588.

Stülke, J., Hanschke, R. \& Hecker, M. (1993). Temporal activation of $\beta$-glucanase synthesis in Bacillus subtilis is mediated by the GTP pool. J Gen Microbiol 139, 2041-2045.

Vallee, B. L., Coleman, J. \& Auld, D. S. (1991). Zinc fingers, zinc clusters, and zinc twists in DNA-binding protein domains. Proc Natl Acad Sci USA 88, 999-1003.

Walker, J. E., Saraste, M., Runswick, M. J. \& Gay, N. J. (1982). Distantly related sequences in the $\alpha$ - and $\beta$-subunits of ATP synthase, myosin, kinases and other ATP-requiring enzymes and a common nucleotide binding fold. EMBO J 1, 945-951.

Yansura, D. G. \& Henner, D. J. (1984). Use of the Escherichia coli lac repressor and operator to control gene expression in Bacillus subtilis. Proc Natl Acad Sci USA 81, 439-443.

Received 10 September 1996; revised 22 November 1996; accepted 5 December 1996. 